\title{
Efficiency of a mine by-product as agricultural liming material and source of zinc
}

\author{
Edilson Cavalli1,* (D), Anderson Lange ${ }^{2}$ (D), Luiz Antonio Junqueira Teixeira ${ }^{3}$ (D), Cassiano Cavalli ${ }^{1}$ (D), \\ Cleide Aparecida de Abreu ${ }^{3}$ (D), Estevão Vicari Mellis ${ }^{3}$ (D) \\ 1. Instituto Agronômico - Programa de Pós-graduação em Agricultura Tropical e Subtropical - Campinas (SP), Brazil. \\ 2. Universidade Federal de Mato Grosso - Instituto de Ciências Agrárias e Ambientais - Sinop (MT), Brazil. \\ 3. Instituto Agronômico - Centro de Solos e Recursos Ambientais - Campinas (SP), Brazil. \\ Received: Nov. 6, 2020 | Accepted: Mar. 10, 2021 \\ Section Editor: Hector Valenzuela \\ *Corresponding author: edilso_c@hotmail.com \\ How to cite: Cavalli, E., Lange, A., Teixeira, L.A.J., Cavalli, C., Abreu, C.A. and Mellis, E.V. (2021). Efficiency of a mine by-product as agricultural \\ liming material and source of zinc. Bragantia, 80, e3221. https://doi.org/10.1590/1678-4499.20200466
}

\begin{abstract}
Most Brazilian soils have restrictions on agricultural use related to acidity and nutrient availability. This study aims to evaluate a zinc $(\mathrm{Zn})$ and lead $(\mathrm{Pb})$ mining by-product (Zincal ${ }^{\mathrm{TM}}$ ), regarding its capacity to correct soil acidity, and to serve as a source of $\mathrm{Zn}$. For evaluation of its efficacy, a comparison with dolomite $+Z n$ sulfate was conducted. The experiment was set up in two soils, a Quartzarenic Neosol and a Red Latosol, and conducted under controlled conditions in the laboratory. Treatments consisted in the application of two doses, aiming at 75 and $95 \%$ base saturation of both liming materials, as well as in a control treatment without acidity correction. The effect of said treatments on $\mathrm{pH}$, base saturation, $\mathrm{Al}^{3+}, \mathrm{H}+\mathrm{Al}, \mathrm{Ca}^{2+}, \mathrm{Mg}^{2+}, \mathrm{Zn}, \mathrm{Mn}$ and $\mathrm{Pb}$ contents were evaluated over 120 days. Similar responses were obtained from both liming materials, regarding their capacity to increase the $\mathrm{pH}$ of the soil, reduce $\mathrm{Al}^{3+}$ and potential acidity $(\mathrm{H}+\mathrm{Al})$, and increase base saturation. Differences observed in these attributes were dose-related. In regard to $\mathrm{Ca}$ and $\mathrm{Mg}$, the content released in soil correlates with the content present in the liming materials. Zincal ${ }^{\mathrm{TM}}$ released more $\mathrm{Mg}$ and less $\mathrm{Ca}$ than dolomite, hence proving to be efficient in releasing Zinc.
\end{abstract}

Key words: waste utilization, residual effect, alternative sources.

\section{INTRODUCTION}

Most tropical soils exhibit some kind of chemical limitation, and soil acidity is a major factor impacting agricultural productivity. According to Quaggio (2000), around 70\% of Brazilian soils are naturally acidic, with low $\mathrm{Ca}$ and $\mathrm{Mg}$ contents, usually combined with high $\mathrm{Al}^{3+}$ availability. In addition to the soils being naturally acidic, successive harvests over the years also acidify the soil due to nitrogen fertilization, organic matter mineralization, and basic cations leaching. Thus, improvement of degraded soils is highly recommended to achieve sustainable productivity (Srivastava and Rai 2012).

A widely used soil amendment strategy consists of liming applications that neutralize soil acidity mitigate $\mathrm{Al}$ and $\mathrm{Mn}$ toxicity and increase $\mathrm{Ca}$ and $\mathrm{Mg}$ contents (Rossetto et al. 2004; 2014), thus creating a more suitable environment for root growth. However, liming reduces some micronutrients availability, particularly zinc ( $\mathrm{Zn}$ ), due to the increase in soil $\mathrm{pH}$ (Mellis et al. 2018). In addition, heavily weathered and leached tropical soils are characterized by a low content of $\mathrm{Zn}$ and other micronutrients (Alloway 2008).

In recent years, a growing number of studies have focused on the agricultural use of industrial by-products and mine tailings in Brazil. Commonly, the search for alternative sources of fertilizers and correctives begins with incubations in laboratory or pot studies, such as Chaves and Farias (2008), with steel slag; Lo Monaco et al. (2012), with ground 
sea shells; Lasso et al (2013), with construction residues; Raimundo et al. (2013), with marble processing waste; and Martins et al (2015), who investigated the effect of silicate rock powder and a manganese mining by-product on the soil chemical properties, among others. In all of these studies, the potential use of these products as a corrective of soil acidity or as a nutrient source was determined. However, Islabão et al. (2014), when studying rice husk ash as a soil acidity corrective, claimed that the scientific advances achieved with studies conducted at laboratory level need to be translated into appropriate technologies for a large-scale use of these alternative products. This translation, according to the authors, should include field studies.

Even though some agricultural inputs still have large natural reserves to be explored, it is important to note that these sources are finite and may become scarce in the future. Therefore, the use of alternative sources, such as industrial and mining residues, is crucial to increase the lifespan of the reserves currently explored and to ensure the sustainability of agricultural production. The purpose of this study was, thus, to evaluate a $\mathrm{Zn}$ and $\mathrm{Pb}$ mine tailing relatively to its capacity to function as a soil acidity neutralizer and as a source of $\mathrm{Zn}$ in a tropical soil.

\section{MATERIAL AND METHODS}

\section{Sampling and soil characterization}

The study was conducted with a sandy soil classified as Quartzarenic Neosol (QN), and a clayey soil, Red Latosol (RL) (Embrapa 2013). Approximately $50 \mathrm{~kg}$ of each soil were collected with a spade from the upper soil layer (0 to $0.2 \mathrm{~m})$ in areas cultivated with sugarcane for over ten years. The RL soil was collected in the municipality of Batatais $\left(20^{\circ} 53^{\prime} 02^{\prime \prime} \mathrm{S}\right.$;

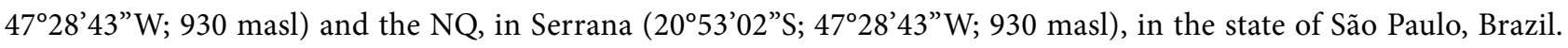
The soils were air dried and sifted with a $2 \mathrm{~mm}$ sieve. Determinations of $\mathrm{pH}\left(\mathrm{CaCl}_{2} 0.01 \mathrm{M}\right)$, potential acidity $(\mathrm{H}+\mathrm{Al}$ with SMP solution), Mn and Zn (DTPA pH 7.3) were performed as described by Raij et al. (2001), while K, Ca and Mg were determined by extraction with ammonium acetate, $1 \mathrm{~mol} \cdot \mathrm{L}^{-1}$ at $\mathrm{pH} 7.0$ (Shuman and Duncan 1990). The particle size was measured by the pipette method (Camargo et al. 1986). Values of sand, silt and clay were 898,15 , and $87 \mathrm{~g} \cdot \mathrm{kg}^{-1}$ for QN and 542, 71, and $387 \mathrm{~g} \cdot \mathrm{kg}^{-1}$ for RL, respectively. Field capacity was $0.07 \mathrm{~g} \cdot \mathrm{g}^{-1}$ for QR and $0.19 \mathrm{~g} \cdot \mathrm{g}^{-1}$ for RL. Soil chemical attributes are shown in Table 1.

Table 1. Soil chemical attributes prior to the application of the treatments. Soils collected in the 0 to $20 \mathrm{~cm}$ layer.

\begin{tabular}{|c|c|c|c|c|c|c|c|c|c|c|c|c|}
\hline \multirow{2}{*}{ Soils } & \multirow{2}{*}{$\mathrm{pH}$} & $\mathbf{K}$ & $\mathrm{Ca}$ & Mg & Al & $\mathrm{H}+\mathrm{Al}$ & SB & CEC & V & m & $\mathrm{Mn}$ & $\mathrm{Zn}$ \\
\hline & & \multicolumn{7}{|c|}{$\longrightarrow \mathrm{mmol}^{\mathrm{c}} \cdot \mathrm{dm}^{-3}-$} & \multicolumn{2}{|c|}{$\%$} & \multicolumn{2}{|c|}{$\mathrm{mg} \cdot \mathrm{dm}^{-3}$} \\
\hline QN & 5.4 & 0.8 & 35 & 6.7 & 0.5 & 22.4 & 42.5 & 64.9 & 65 & 1.2 & 4.5 & 0.8 \\
\hline $\mathrm{RL}$ & 5.2 & 3.2 & 29 & 7.7 & 1.0 & 29.9 & 39.9 & 69.8 & 57 & 2.5 & 32.2 & 1.9 \\
\hline
\end{tabular}

$\mathrm{QN}=$ Quartzarenic Neosol; RL = Red Latosol; $\mathrm{SB}=$ sum of bases; $\mathrm{CEC}=$ cation exchange capacity; $\mathrm{V}=$ soil base saturation; $\mathrm{m}=$ soil aluminum saturation .

\section{Characterization of liming materials}

$\mathrm{A} \mathrm{Zn}$ and $\mathrm{Pb}$ mine tailing from Paracatu, in the state of Minas Gerais, Brazil, was evaluated as agricultural liming material. This product, properly licensed as soil acidity corrective $\left(Z_{i n c a l}{ }^{m+1}\right)$ derives from galena and sphalerite ore exploration. Raw ore is transformed into lead sulfide $(\mathrm{Pb})$ and zinc $(\mathrm{Zn})$ concentrates, generating, as a by-product, an agricultural liming material.

For assessment of this by-product, both as an agricultural liming material and as a source of $\mathrm{Zn}$, a comparison with dolomite and dolomite $+\mathrm{Zn}$ sulfate $\left(\mathrm{ZnSO}_{4} \cdot 7 \mathrm{H}_{2} \mathrm{O}\right)$ was conducted. The liming materials characterization, according to Brazil (2014), is shown in Table 2. 
Table 2. Characterization of liming materials.

\begin{tabular}{|c|c|c|c|c|c|c|c|c|c|c|c|}
\hline \multirow{2}{*}{$\begin{array}{l}\text { Liming } \\
\text { material }\end{array}$} & $\mathrm{CaO}$ & $\mathrm{MgO}$ & CCE & RE & ENV & Cd & $\mathrm{Pb}$ & $M n$ & $\mathrm{Zn}-\mathrm{HCl}^{\mathrm{a}}$ & $\mathrm{Zn}-\mathrm{CA}^{\mathrm{b}}$ & $\mathrm{Zn}-\mathrm{NAC} \mathrm{C}^{\mathrm{C}}$ \\
\hline & \multicolumn{5}{|c|}{ - $\%$} & \multicolumn{6}{|c|}{$\longrightarrow \mathrm{mg} \cdot \mathrm{kg}^{-1} \longrightarrow$} \\
\hline $\begin{array}{l}\text { Dolomite } \\
\text { (DOL) }\end{array}$ & 44.4 & 9.5 & 103.5 & 99.0 & 102.4 & $<1$ & 5 & $<1$ & 21 & - & - \\
\hline Zincal $^{\mathrm{TM}}(\mathrm{ZIN})$ & 27.5 & 17.2 & 92.3 & 98.8 & 91.2 & 11 & 504 & 3900 & 3300 & 1878 & 1796 \\
\hline
\end{tabular}

$\mathrm{CCE}=$ calcium carbonate equivalent; $\mathrm{RE}=$ reactivity (fineness of griding); $\mathrm{ENV}=$ effective neutralizing value $(\mathrm{ENV}=\mathrm{CCE} \times \mathrm{RE} / 100$ ).

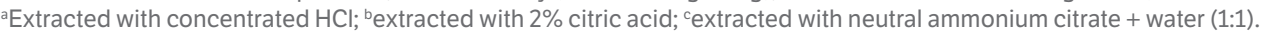

\section{Experimental design}

The experiment was conducted in the laboratory at the Agronomic Institute (IAC; from Portuguese, Instituto Agronômico de Campinas), in the city of Campinas, Brazil. The experimental design for both soils was entirely randomized, consisting of $1.2 \mathrm{~kg}$ soil samples in which five treatments with three replications were set up, as described in Table 3. Each sample was divided into four $0.3 \mathrm{~kg}$ subsamples and incubated in $0.35 \mathrm{dm}^{3}$ pots for analysis over time. Liming material, dolomite (DOL) and Zincal ${ }^{\mathrm{ma}}$ (ZIN), doses were determined by the base saturation method (Raij et al. 1997), aiming to reach V of 75 (DOL75 and ZIN75) and 95\% (DOL95 and ZIN95), as shown in Table 3. Considering an ENV of 100\%, the liming material doses to achieve $\mathrm{V}$ of $75 \%$, were 0.7 and $1.9 \mathrm{Mg} \cdot \mathrm{ha}^{-1}$ for QN and $\mathrm{RL}$, respectively. For $\mathrm{V}=95 \%$, the doses were 1.17 and 2.6 Mg.ha ${ }^{-1}$ for QN and RL, respectively. Samples treated with DOL also received doses of Zn sulfate calculated to provide the equivalent $\mathrm{Zn}$ quantities contained in $\mathrm{Zincal}^{\mathrm{m}}$. After treatment applications, soil samples were homogenized and incubated for 2, 30, 60 and 120 days, maintaining the humidity between 60 and $80 \%$ of field capacity. Soil moisture was checked by weighing the pots every 4 or 5 days and adjusted by adding deionized water.

Table 3. Treatments with doses of liming materials and $\mathrm{Zn}$ in two tropical soils, São Paulo, Brazil.

\begin{tabular}{|c|c|c|c|c|}
\hline \multirow{3}{*}{ Treatment } & \multicolumn{2}{|c|}{ Quartzarenic Neosol } & \multicolumn{2}{|c|}{ Red Latosol } \\
\hline & Liming material & $Z^{a}$ & Liming material & $Z^{a}$ \\
\hline & \multicolumn{4}{|c|}{$\longrightarrow \mathrm{mg} \cdot \mathrm{kg}$ of soil $^{-1}$} \\
\hline Control & 0 & 0 & 0 & 0 \\
\hline Dolomite 75 (DOL75) & 342 & 1.27 & 525 & 1.93 \\
\hline Dolomite 95 (DOL95) & 945 & 3.50 & 1275 & 4.70 \\
\hline Zincal $^{\mathrm{TM}} 75$ (ZIN75) & 383 & - & 588 & - \\
\hline Zincal $^{\text {TM }} 95$ (ZIN95) & 1059 & - & 1429 & - \\
\hline
\end{tabular}

\section{Analyses}

\section{Soil chemical analysis}

Treatment effects on soil chemical attributes were determined in all incubation periods. Contents of $\mathrm{Ca}, \mathrm{Mg}$, and $\mathrm{K}$ availability were estimated by extraction with $1 \mathrm{~mol} \cdot \mathrm{L}^{-1}$ ammonium acetate at $7.0 \mathrm{pH}$ with modifications (Shuman and Duncan 1990). For that purpose, $2.5 \mathrm{~cm}^{-3}$ of soil and $25 \mathrm{~mL}$ of extraction solution were added to an Erlenmeyer, and subsequently 
centrifuged for 15 minutes at $21 \mathrm{rad} \cdot \mathrm{s}^{-1}$. After decanting for 16 hours, $1.0 \mathrm{~mL}$ of the supernatant diluted in $10 \mathrm{~mL}$ of $0.1 \%$ lanthanum was removed for reading in an atomic absorption spectrophotometer. Additional soil chemical analyses were conducted according to Raij et al. (2001) for determination of $\mathrm{pH} \mathrm{CaCl}_{2}(0.01 \mathrm{M}) ; \mathrm{H}+\mathrm{Al}$ was determined by SMP solution, and micronutrients and $\mathrm{Pb}$ by DTPA $7.3 \mathrm{pH}$. Based on values obtained from those analyses, the base saturation of the soils under study was calculated.

\section{Exchangeable and non-exchangeable calcium and magnesium}

The determination of exchangeable and non-exchangeable $\mathrm{Ca}$ and $\mathrm{Mg}$ content was carried out only in samples collected on the $120^{\text {th }}$ day after incubation (DAI), according to Quaggio et al. (1995). In a percolating tube, $10 \mathrm{~cm}^{3}$ of soil were placed on slow filtering papers. Thereafter, four times the volume of $25 \mathrm{~mL}$ of $\mathrm{KCl} 1 \mathrm{~mol} \cdot \mathrm{L}^{-1}$ was percolated. The percolated extract was collected in a $100-\mathrm{mL}$ volumetric flask, and the volume was corrected with deionized water. In a $0.5-\mathrm{mL}$ aliquot from the extract obtained, $10 \mathrm{~mL}$ of $0.1 \%$ lanthanum solution were added and subsequently read by the atomic absorption spectrophotometry. After deducting the values from the control treatment, where no correctives were added, the results indicated exchangeable $\mathrm{Ca}$ and $\mathrm{Mg}$ contents in the soil where correctives had been added, i. e., the fraction of correctives that had already been reacted in the soil. The same extract was used to obtain the content of exchangeable A1 in soil, and the reading followed the same methodology for $\mathrm{KCl}$ extraction, as described in Raij et al. (2001).

After the first extraction, the soil was transferred to a $200-\mathrm{mL}$ test tube and a $30-\mathrm{mL}$ of water maximum was used to transfer the soil from the percolating tube to the test tube for determining non-exchangeable $\mathrm{Ca}$ and $\mathrm{Mg}$ contents. After transferring, a $50-\mathrm{ml}$ of $\mathrm{HCl} 0.8 \mathrm{~mol} \cdot \mathrm{L}^{-1}$ solution was added. Thereafter, the whole content was boiled on a hot plate for 10 minutes $(\sim 200 \mathrm{oC})$. Thus, by boiling the soil together with the action of hydrochloric acid $(\mathrm{HCl})$, the remaining corrective was forced to react (fast dissolving). After this process, the sample was cooled, the material filtered in a slow filtering paper, the extract transferred to a 100-mL volumetric flask, and the volume filled up with deionized water. Subsequently, $1 \mathrm{~mL}$ extract was diluted in $10 \mathrm{~mL}$ of $0.5 \%$ lanthanum for determination of non-exchangeable $\mathrm{Ca}$ and $\mathrm{Mg}$ contents by spectrophotometer reading. After deducting the values from the control treatment, to which no correctives had been added, the results indicated the fractions of correctives that had not been reacted in soil.

\section{Statistical Analysis}

Data were submitted to variance analysis, and, when significant (F-test; $\mathrm{p}<0.05$ ), a comparison of means was performed by Tukey`s HSD test, using SISVAR $^{\mathrm{mm}}$ statistical analysis system, version 5.6 (Ferreira 2011).

\section{RESULTS AND DISCUSSION}

The liming materials applied proved to be efficient in neutralizing soil acidity, showing similar responses regardless of the evaluated soil (Figs. 1a and 1b). This indicates that, for the purpose of correcting soil acidity, Zincal ${ }^{\mathrm{m}}{ }^{\mathrm{m}}$ is as efficient as dolomite, being a potential alternative source of corrective.

Regarding the reactivity, both correctives showed rapid reaction in soil, as increases in $\mathrm{pH}$ two days after incubation were very close to the maximum values obtained between 30 and $60 \mathrm{DAI}$ (Fig. 1). In general, the pH values obtained with application of correctives varied between 5.5 and 6.2, being in a range considered ideal for most crops (Raij et al. 1997). The observed results of such a rapid change in $\mathrm{pH}$ may have been affected by the small volume of soil $\left(0.3 \mathrm{dm}^{3}\right)$ incubated in each pot. Other variables that also reflect the reactivity of the materials, such as $\mathrm{Ca}$ and $\mathrm{Mg}$ availability and base saturation, increased over the incubation period (Fig. 2). 
(a)

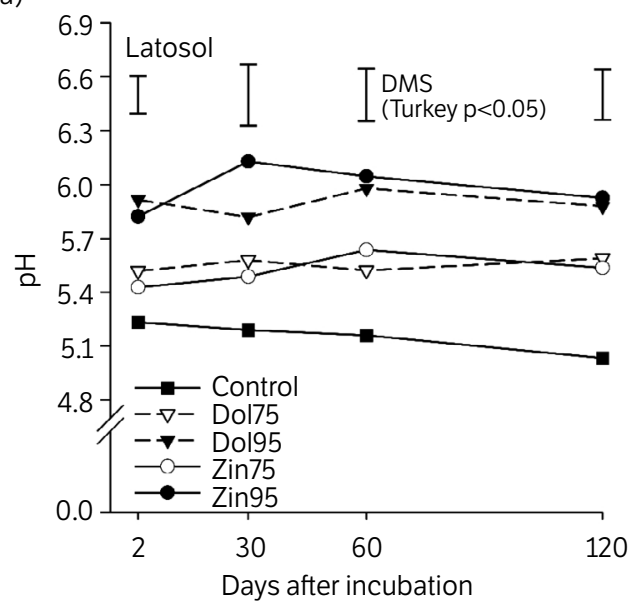

(c)

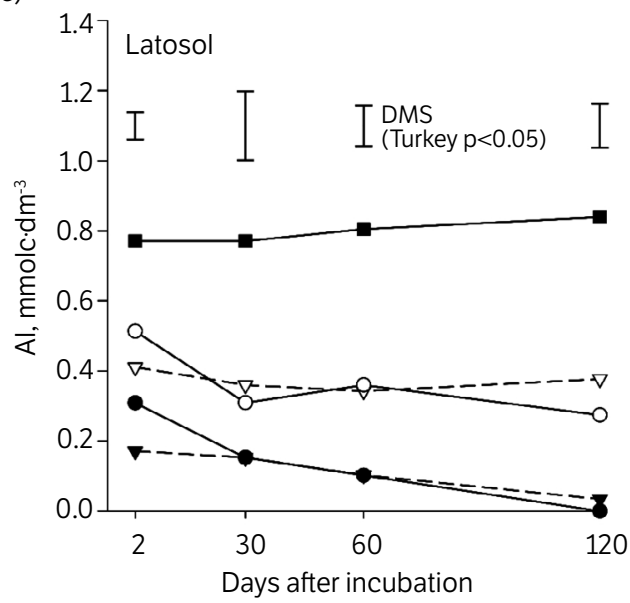

(e)

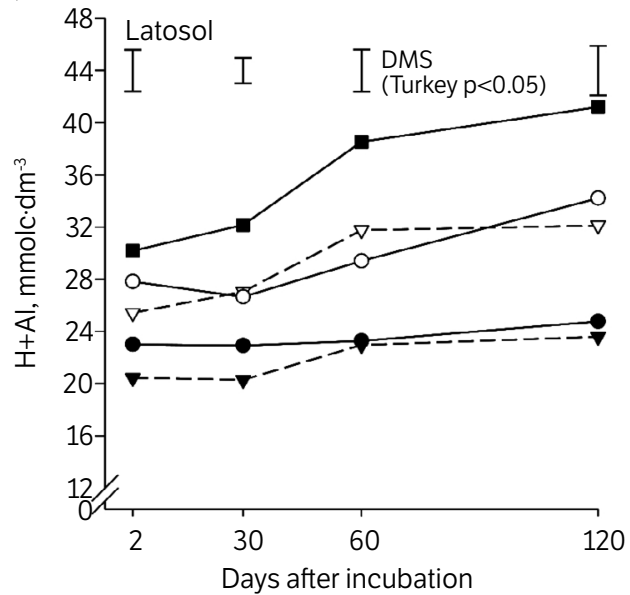

(b)

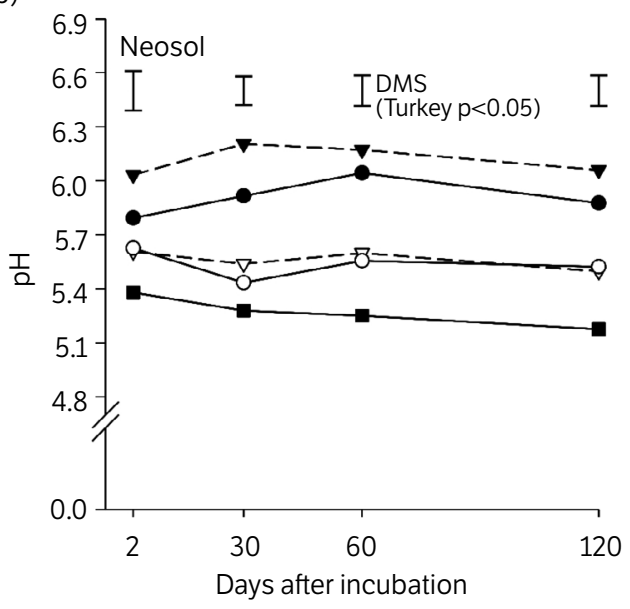

(d)

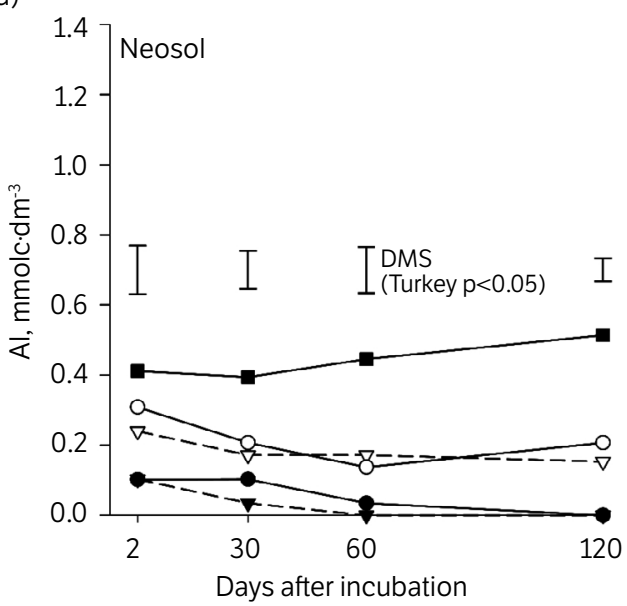

(f)

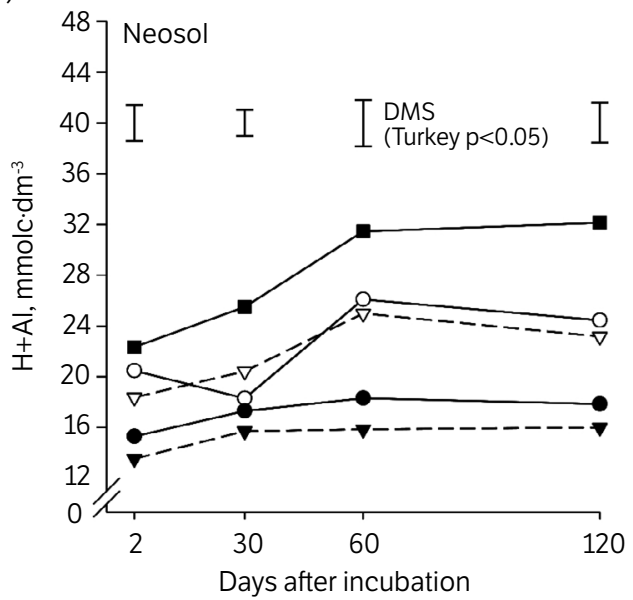

Figure 1. Effect of treatment on the soil pH - (a) Red Latosol; (b) Neosol - on Al ${ }^{3+}$ concentration - (c) Red Latosol; (d) Quartzarenic Neosol -, as well as on potential acidity ( $\mathrm{H}+\mathrm{A} 1)-(\mathrm{e})$ Red Latosol; ( $\mathrm{f})$ Quartzarenic Neosol.

DOL75 and DOL95: application of dolomite aiming to reach base saturation of 75 and 95\%, respectively; ZIN75 and ZIN95: application of Zincal ${ }^{\mathrm{TM}}$ aiming to reach base saturation of 75 and $95 \%$, respectively. 
(a)

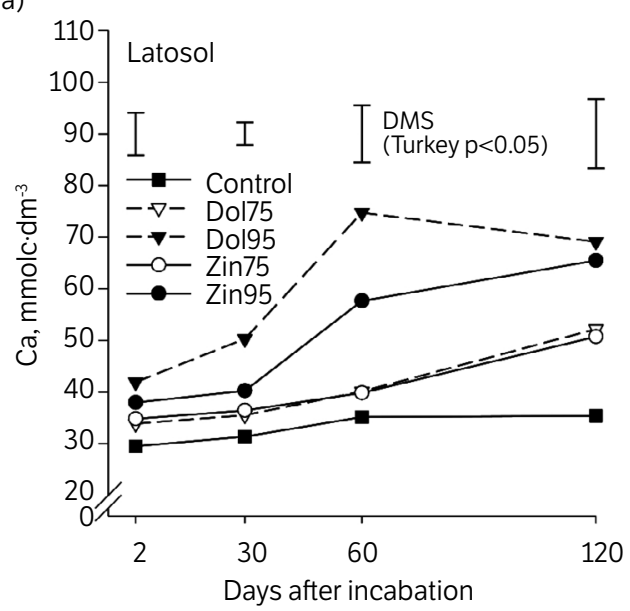

(c)

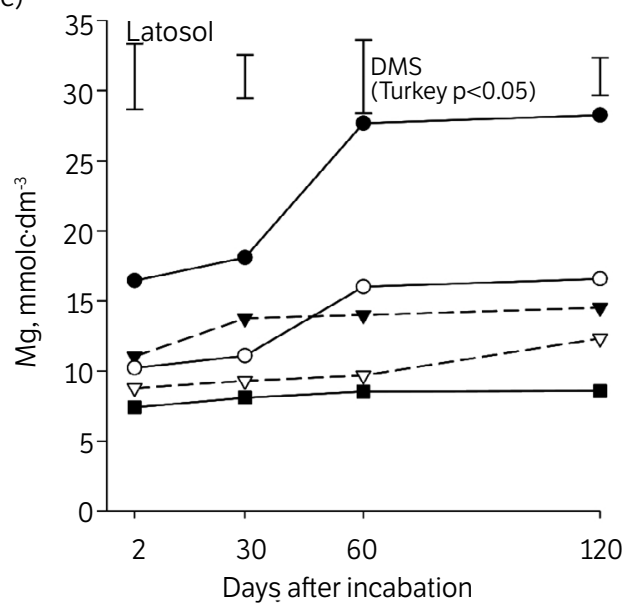

(e)

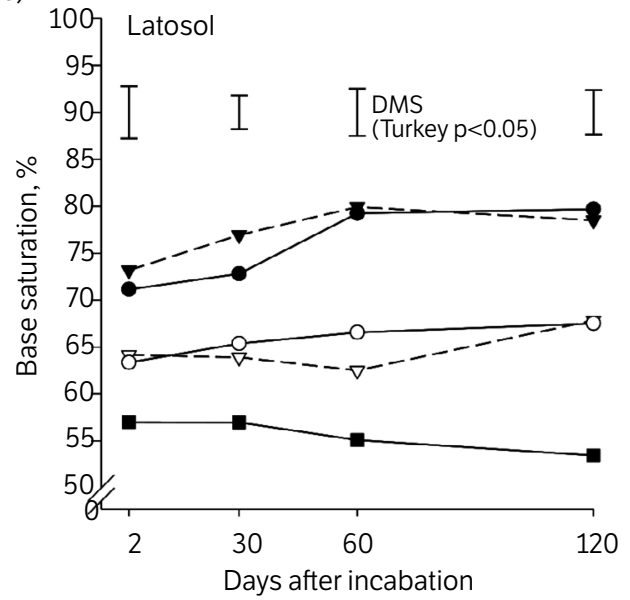

(b)

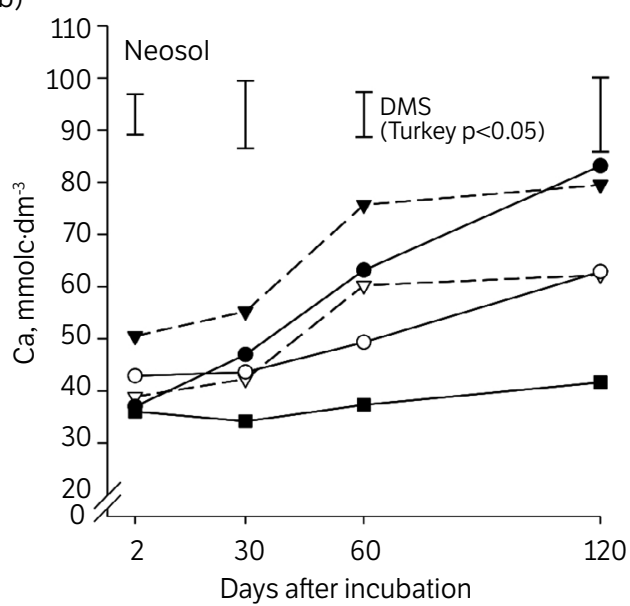

(d)

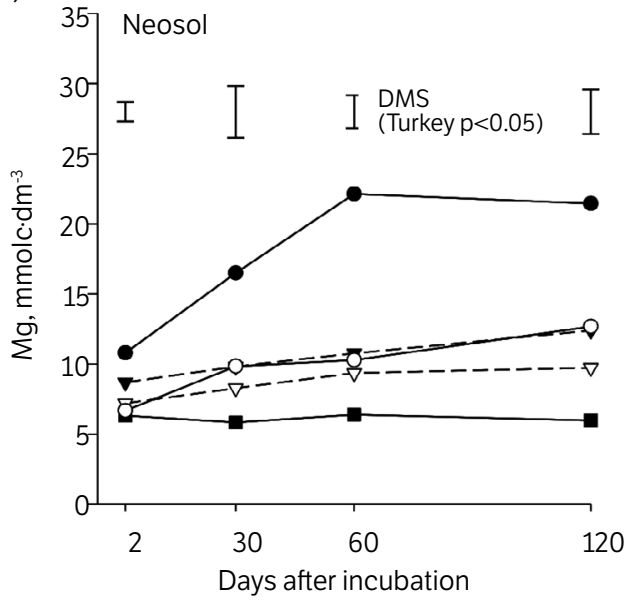

(f)

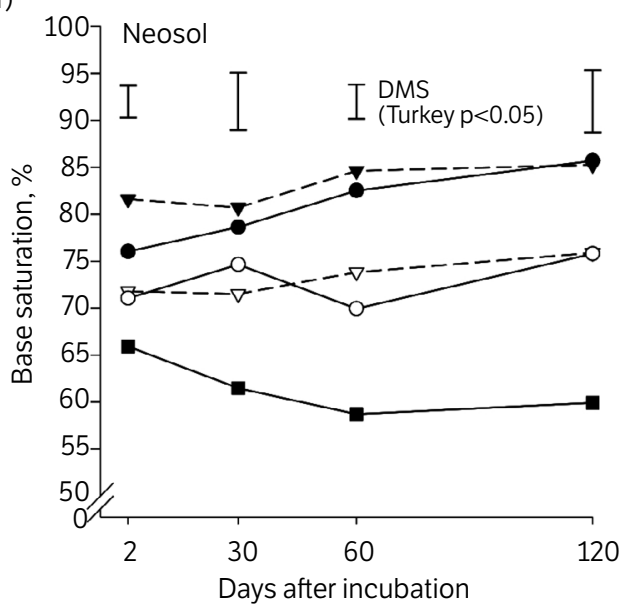

Figure 2. Treatment effects on soil Ca - (a) Red Latosol; (b) Quartzarenic Neosol - and Mg availability - (c) Red Latosol; (d) Quartzarenic Neosol -, as well as on base saturation - (e) Red Latosol; (f) Quartzarenic Neosol.

DOL75 and DOL95: application of dolomite aiming to reach base saturation of 75 and 95\%, respectively; ZIN75 and ZIN95: application of Zincal TM $^{\mathrm{T}}$ iming to reach base saturation of 75 and $95 \%$, respectively. 
The initial $\mathrm{Al}^{3+}$ content in soils was low, in the order of 0.5 and $1.0 \mathrm{mmol}_{\mathrm{c}} \cdot \mathrm{dm}^{-3}$, and A1 saturation was 1 and $2 \%$ for the Neosol and Latosol soils, respectively see (Table 1). Despite its low content in soil, the increase in soil pH caused by liming further reduced $\mathrm{Al}^{3+}$ availability in both soils (Figs. $1 \mathrm{c}$ and $1 \mathrm{~d}$ ). The treatments showed a rapid reduction in $\mathrm{Al}^{3+}$ availability in the first two days of incubation. In the Latosol, a slight difference between the types of correctives was observed on the 2nd DAI, with Zincal ${ }^{\text {mw }}$ being less effective in decreasing $\mathrm{Al}^{3+}$ availability. However, after the 30th DAI, both correctives showed almost the same effect regarding $\mathrm{Al}^{3+}$ availability. The faster reaction of dolomite is probably due to the higher concentration of $\mathrm{Mg}$ in $\mathrm{Zincal}^{\mathrm{im}}$. According to Barber (1984), the rate of dissolution is affected by the $\mathrm{Mg}$ content of the liming material. Throughout the incubation period, the effects of liming materials were predominantly determined by the applied doses. Both correctives, when used in their maximum dose, reduced the exchangeable content of $\mathrm{Al}^{3+}$ to zero. However, the reaction occurred more rapidly in the QN (60 DAI) than in the RL (120 DAI), probably due to the lower buffer capacity of $\mathrm{QN}$. The potential acidity $(\mathrm{H}+\mathrm{Al})$ showed a similar response to that of $\mathrm{Al}^{3+}$ to the applied doses of both liming materials.

Over time, a small increase in potential acidity and $\mathrm{Al}^{3+}$ availability was observed in the control treatment, as well as a reduction in soil pH (Fig. 1). These changes may be a consequence of acidification caused by soil organic matter decay, as the conditions of moisture and aeration of the soil during incubation favored microbial activity. In treatments aimed at increasing the base saturation to 75\% (ZIN75 and DOL75), both the potential acidity and Al ${ }^{3+}$ did not vary significantly over the incubation period. Apparently, the amount of corrective applied was sufficient to create a buffer effect on the soil, preventing its acidification. DOL95 and ZIN95 treatments showed significant reductions in potential acidity and $\mathrm{Al}^{3+}$ availability during the incubation period. Although enlightening the potential effects of the liming materials studied, the dynamics of the observed reactions cannot be immediately transferred to field conditions. Both the acidification processes and the reaction of liming materials occur in different ways under field conditions when compared to the laboratory environment. For example, the closed system of a pot, even though it allows gas exchange with the environment, cannot mimic the constant movement of water and nutrients observed in the soil.

As shown in Table 2, the liming materials presented differences in their composition, which probably influenced the changes in the soil availability of $\mathrm{Ca}^{2+}$ and $\mathrm{Mg}^{2+}$ observed during incubation. Dolomite-treated soils showed faster increases in $\mathrm{Ca}^{2+}$ availability than those receiving $\mathrm{Zincal}^{\mathrm{m}}$. However, by the 120th DAI, the content of $\mathrm{Ca}^{2+}$ in the treatment with ZIN95 was the same as that of DOL95 (Figs. 2a and 2b). Probably, also as a result of the composition of the liming materials, the largest increments of $\mathrm{Mg}^{2+}$ were observed with the application of Zincal ${ }^{\mathrm{m}}$, especially with the ZIN95 treatment (Fig. 2c and 2d).

As for the $\mathrm{Ca}^{2+}$ content in soil, even being high prior to treatment applications ( $>7 \mathrm{mmol}_{\mathrm{c}} \cdot \mathrm{dm}^{-3}$; Raij et al. 1997), a great increase, resulting from applications of correctives, was observed in both soils studied (Figs. $2 \mathrm{a}$ and $2 \mathrm{~b}$ ). In response to the correctives applied, by the $120^{\text {th }} \mathrm{DAI}, \mathrm{Ca}^{2+}$ availability varied between 50 and $69 \mathrm{mmol}_{\mathrm{c}} \cdot \mathrm{dm}^{-3}$ in the Latosol, and between 62 and $83 \mathrm{mmol} \cdot \mathrm{dm}^{-3}$ in the Neosol. Likewise, $\mathrm{Mg}$ availability varied from 12 to $28 \mathrm{mmol}_{\mathrm{c}} \cdot \mathrm{dm}^{-3}$ in the Latosol, and between 10 and $22 \mathrm{mmol}_{\mathrm{c}} \cdot \mathrm{dm}^{-3}$ in the Neosol (Figs. 2c and 2d).

Changes in $\mathrm{Ca}$ and $\mathrm{Mg}$ availability, resulting from the application of the two correctives, altered the Ca: $\mathrm{Mg}$ ratio in the soil. By the 120th DAI, the control treatment in the Latosol showed a Ca:Mg ratio of 4:1, changed to 5:1 with the addition of dolomite, regardless of the dose applied. By its turn, with ZIN75 and ZIN95, the ratio decreased to $3: 1$ and 2:1, respectively. In the Neosol, the control treatment Ca:Mg ratio, initially at 7:1, did not change with dolomite application. However, with ZIN75 and ZIN95, Ca:Mg ratio decreased to 5:1 and 4:1, respectively. These changes in this type of soil ratio after liming are due to differences regarding the inherent $\mathrm{Ca}: \mathrm{Mg}$ ratio of the liming materials, approximately 6:1 for dolomite and 2:1 for Zincal ${ }^{\mathrm{m}}$, respectively. This is a feature that can be considered by farmers as a criterion for the selection of correctives to be applied: considering the Ca:Mg of the soil and the crop requirements. Although some agronomists consider 4 to 6 a benchmark for the soil Ca:Mg ratio, this claim has not been validated for several crops. As long as gross imbalances were not created, there was often no correlation observed between soil Ca:Mg ratio and crop yield responses (Moser 1933; Simon et al. 1979; McLean and Brown, 1984; Haby et al., 1993). 
Even considering the differences observed in $\mathrm{Ca}^{2+}$ and $\mathrm{Mg}^{2+}$ contents released by the correctives, the base saturation showed differences only as a function of the dose applied, regardless of the type of corrective (Figs. 2e and 2f). The treatments were efficient in increasing the base saturation in both soils studied, and both correctives showed virtually the same results. The treatments showed greater responses in the Neosol, achieving a maximum saturation of 81 and $91 \%$, respectively, for doses applied to reach 75 and $95 \%$ saturation. However, in the Latosol, the base saturation reached 72 and $84 \%$ for the same doses. These differences observed in base saturation after liming are due to the buffer capacity of each soil. The RL, due to its greater buffering capacity, showed an increase in base saturation slightly lower than that observed in the NQ. The most pronounced reaction in the Neosol relates to its characteristics, such as lower potential CTC, and lower clay and iron contents (1.7-fold lower than Latosol), which give greater potential for a liming response.

The saturation values obtained at the end of 120 days of incubation were either closer or higher than those expected, owing to the fact that the experiment was carried out in a laboratory closed system, with no chances of base losses in underlying soil layers, as well as no influence of plants on soil acidification $\left(\mathrm{H}^{+}\right.$release by roots) or base removal from absorption by plants. Calonego et al. (2012), under similar conditions to the present study, obtained greater saturation than expected. However, when the experiment is conducted under field conditions, the value of the base saturation normally obtained is quite below the expected result (Rosseto et al. 2014, Morelli et al. 1992).

Table 4. Exchangeable (E) and non-exchangeable (NE) Ca and $\mathrm{Mg}$ in the soil and percentage of liming material that had reacted at 120 days after incubation.

\begin{tabular}{|c|c|c|c|c|c|c|c|c|}
\hline \multirow[b]{2}{*}{ Treatments } & \multicolumn{4}{|c|}{ Red Latosol } & \multicolumn{4}{|c|}{ Quartzarenic Neosol } \\
\hline & CaE & Ca NE & $\mathrm{MgE}$ & $\mathrm{Mg} \mathrm{NE}$ & CaE & Ca NE & $\mathrm{MgE}$ & Mg NE \\
\hline DOL75 & $15.5 b$ & $2.3 \mathrm{~b}$ & $4.2 \mathrm{c}$ & $1.6 \mathrm{~b}$ & $8.3 \mathrm{~b}$ & $3.6 \mathrm{~b}$ & $1.6 \mathrm{c}$ & $1.5 \mathrm{~b}$ \\
\hline DOL95 & $33.5 \mathrm{a}$ & $6.4 \mathrm{a}$ & $8.7 \mathrm{~b}$ & $2.8 \mathrm{~b}$ & $19.3 \mathrm{a}$ & $10.9 \mathrm{a}$ & $4.7 \mathrm{~b}$ & $1.9 \mathrm{a}$ \\
\hline ZIN75 & $12.5 \mathrm{c}$ & $2.6 \mathrm{~b}$ & $8.0 \mathrm{~b}$ & $2.9 \mathrm{~b}$ & $8.9 \mathrm{~b}$ & $4.5 \mathrm{~b}$ & $6.5 \mathrm{~b}$ & $0.7 c$ \\
\hline ZIN95 & $17.7 \mathrm{~b}$ & $7.5 \mathrm{a}$ & $15.5 \mathrm{a}$ & $7.0 \mathrm{a}$ & $18.0 \mathrm{a}$ & $12.9 \mathrm{a}$ & $13.6 \mathrm{a}$ & $1.3 \mathrm{~b}$ \\
\hline Average & 19.8 & 4.7 & 9.1 & 3.6 & 13.6 & 8.0 & 6.6 & 1.35 \\
\hline CV (\%) & 4.89 & 27.44 & 9.81 & 14.92 & 6.92 & 13.83 & 14.08 & 7.6 \\
\hline$p$-value & $<0.001$ & 0.002 & $<0.001$ & $<0.001$ & $<0.001$ & $<0.001$ & $<0.001$ & $<0.001$ \\
\hline & $\mathrm{Ca}$ & Mg & $\mathrm{Ca}+\mathrm{Mg}$ & & $\mathrm{Ca}$ & Mg & $\mathrm{Ca}+\mathrm{Mg}$ & \\
\hline DOL75 & 87 & 72 & 80 & & 70 & 52 & 61 & \\
\hline DOL95 & 83 & 75 & 79 & & 64 & 71 & 68 & \\
\hline ZIN75 & 82 & 73 & 78 & & 66 & 90 & 78 & \\
\hline ZIN95 & 70 & 69 & 70 & & 58 & 91 & 75 & \\
\hline
\end{tabular}

Values in a column followed by equal letters do not differ statistically according to the Tukey `s HSD test $(p<0.05)$. 
During the period of 120 days of the experiment, both liming materials showed very similar effects. Thus, in order to estimate their residual effect, the exchangeable and non-exchangeable $\mathrm{Ca}$ and $\mathrm{Mg}$ contents were quantified. (Table 4). For both soils and correctives, it was observed that over $60 \%$ of limestone applied had already reacted in the soil by the end of the 120-day incubation period. This result corroborates with Mello et al. (2003), who concluded that the finer particles of limestone $(<0.30 \mathrm{~mm})$ react in up to three months in soil, with coarser particles reacting subsequently.

In the Latosol, a quite similar reaction was observed among correctives with the DOL75, DOL95, and ZIN75 treatments, showing that $79 \%$ of correctives had already been reacted, while, with ZIN95, the reaction was $70 \%$ by the $120^{\text {th }}$ DAI. In the Neosol, a lower reactivity for dolomite (DOL75 $=61 \%$, DOL95 $=68 \%$ ) was observed, being practically equal to Zincal $^{\text {mi }}$ (ZIN75 $=78 \%$; ZIN95 $\left.=75 \%\right)$.

A quick reaction may be important when implanting a culture. However, it is worth mentioning that this will result in a lower residual effect. Studies by Raij et al. (1982) on liming residual effects on tropical soils demonstrated that the exchangeable content of $\mathrm{Ca}^{2+}+\mathrm{Mg}^{2+}$ was reduced from 32.5 to $27.8 \mathrm{mmol}_{c} \cdot \mathrm{dm}^{-3}$, while the non-exchangeable content was reduced from 98.4 to $29.9 \mathrm{mmol} \cdot \mathrm{dm}^{-3}$ over a period of 5 years. The authors concluded that, when a coarse limestone is utilized, the non-exchangeable content gradually changes into exchangeable content over time.

Zincal $^{\text {tw }}$ showed to be efficient in releasing $\mathrm{Zn}$ to soil. However, the $\mathrm{Zn}$ content available in soils treated with Zincal $^{\text {tw }}$ was $50 \%$ lower than in soils treated with an equivalent application of this micronutrient via $\mathrm{Zn}$ sulfate (Figs. 3a and 3b). This lower $\mathrm{Zn}-\mathrm{Zincal}^{\mathrm{m}}{ }^{\mathrm{x}}$ reactivity is related to its solubility. Table 2 shows that approximately $55 \%$ of the total $\mathrm{Zn}$ (extracted with $\mathrm{HCI}$ ) contained in the corrective were recovered by neutral ammonium citrate and citric acid, with values that were compatible with the quantities released by Zincal ${ }^{\mathrm{mw}}$. In addition, it was observed that the $\mathrm{Zn}$ released by both products was fast, since, in only 2 days after incubation, the $\mathrm{Zn}$ content available in soils was nearly the same as those determined by the $120^{\text {th }}$ DAI.

Despite the lower $\mathrm{Zn}$ released by $\mathrm{Zincal}^{\mathrm{m}}$, the $\mathrm{Zn}$ made available in the soil per ton of applied corrective ( $1 \mathrm{mg} \cdot \mathrm{dm}^{-3}$, except for ZIN75 treatment in the Latosol $=0.5 \mathrm{mg} \cdot \mathrm{dm}^{-3}$ ) was sufficient to meet the demands of most crops (Raij et al. 1997). Currently, the application of $\mathrm{Zn}$ in soil is done in a concentrated form, mainly through the use of a mixture of granules, fertilizers covered with $\mathrm{Zn}$, or individual sources, such as $\mathrm{Zn}$ sulfate, oxide and chelate. Those technologies, although in use, are not usually capable of increasing $\mathrm{Zn}$ availability levels in soil, due to its low concentration in fertilizers and the difficulty in applying high doses of fertilizers, which, in addition to presenting operational difficulties, can increase the cost of production. Also, the application of conventional correctives decreases $\mathrm{Zn}$ availability in tropical soils, due to their adsorption with increased pH (Mellis et al. 2018, Pegorato et al. 2006), making the use of this by-product, as studied here, a potential strategy for increasing $\mathrm{Zn}$ availability in soil.

In general, a slightly greater availability of $\mathrm{Mn}$ was observed in the control treatment, even with Zincal ${ }^{\mathrm{Tm}}$ application (Figs. 3c and 3d). Probably, the high Mn content of Zincal ${ }^{\text {Tw }}$ (Table 2) is contained in sparingly soluble forms. In addition, the detrimental effects of soil acidity correctives on Mn availability have been reported in the literature (Mellis et al. 2018; Pegoraro et al. 2006), which may explain the slightly greater availability of Mn in the control treatment.

The total $\mathrm{Pb}$ contents in the soils studied here were low prior to the apllications of the treatments: $3 \mathrm{mg} \cdot \mathrm{kg}^{-3} \mathrm{in}$ the Latosol, and $2 \mathrm{mg} \cdot \mathrm{kg}^{-3}$ in the Neosol. Although $\mathrm{Pb}$ content of Zincal ${ }^{\mathrm{m}}$ was higher in comparison with dolomite (Table 2), it was within the limits established by Brazilian legislation (up to $1000 \mathrm{mg} \cdot \mathrm{kg}^{-1}$ ) (Brazil 2006). Even so, in order to check the possible environmental impact of the liming materials, the soil $\mathrm{Pb}$ availability was evaluated according to the doses, and the incubation period (Figs. 3e and 3d). Dolomite application reduced the $\mathrm{Pb}$ availability when compared to the control over time. For Zincal ${ }^{\mathrm{m}}$, even with the increase of $\mathrm{pH}$ due to its application, there was a significant increase in the soil $\mathrm{Pb}$ availability. Even so, the increase in this availability was very low, presenting no significant risk of soil contamination. 
(a)

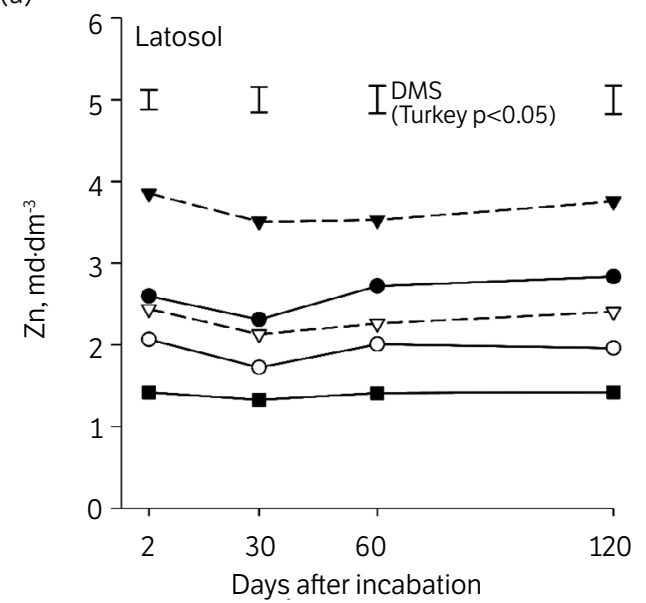

(c)

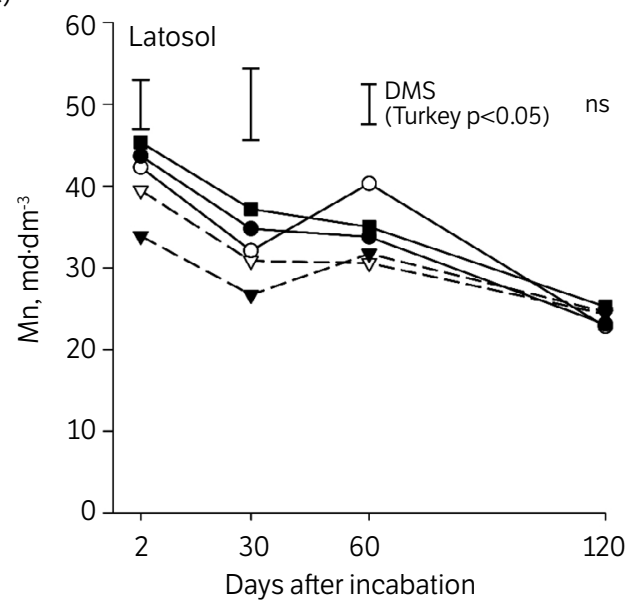

(e)

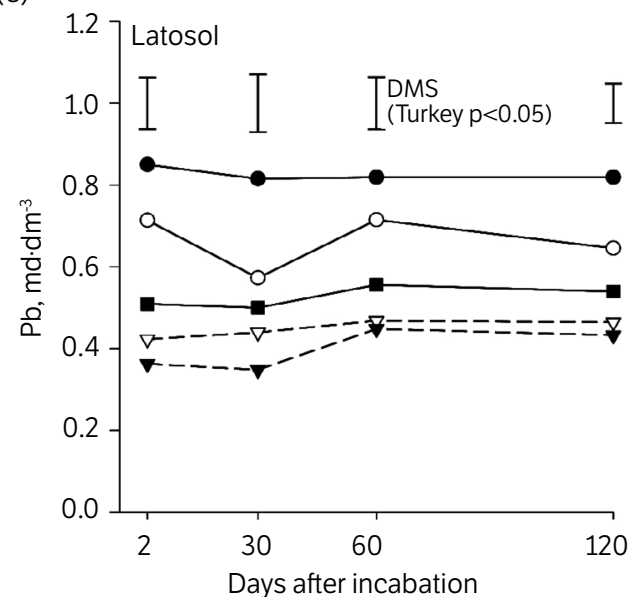

(b)

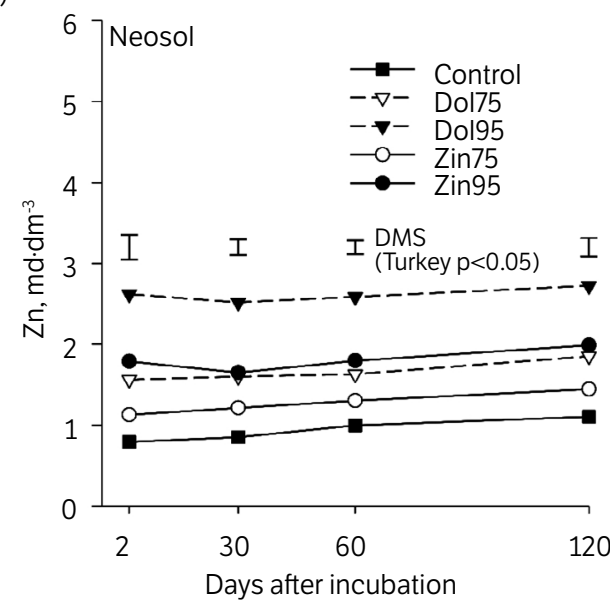

(d)

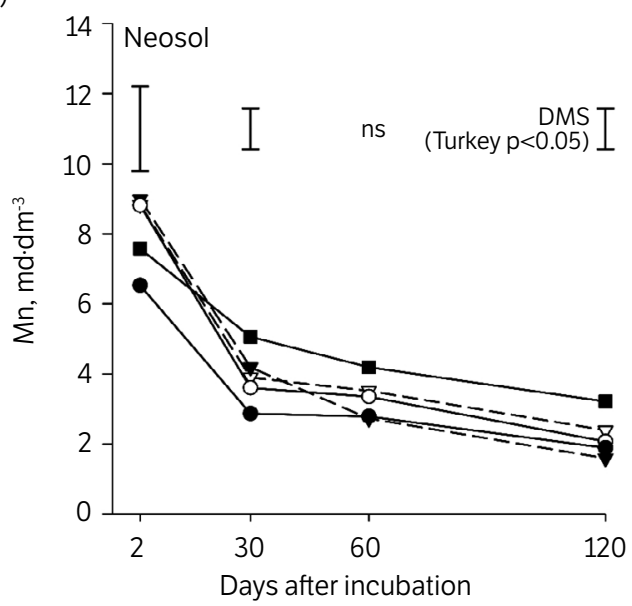

(f)

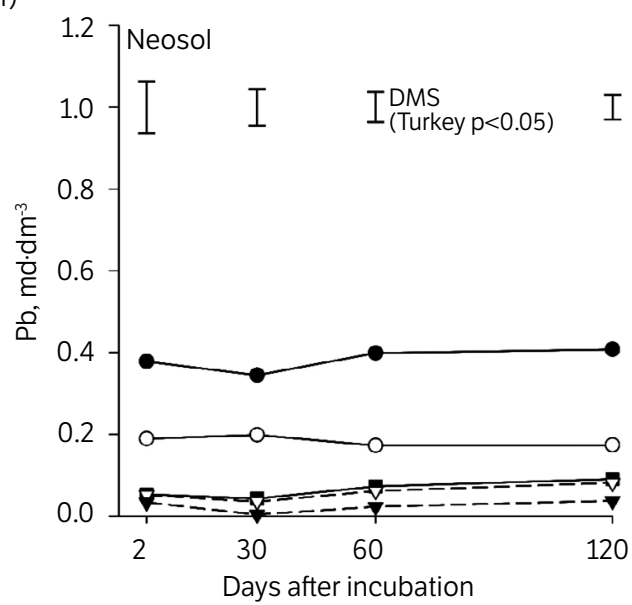

Figure 3. Effect of treatments on Zn-(a) Red Latosol; (b) Quartzarenic Neosol-, Mn concentration - (c) Red Latosol; (d) Quartzarenic Neosol-, as well as Pb availability in soil - (e) Red Latosol; (f) Quartzarenic Neosol.

DOL75 and DOL95: application of dolomite aiming to reach base saturation of 75 and 95\%, respectively; ZIN75 and ZIN95: application of Zincal ${ }^{T M}$ aiming to reach base saturation of 75 and $95 \%$, respectively. 


\section{CONCLUSION}

The mining by-product, Zincal ${ }^{\mathrm{mt}}$, has the same effectiveness in soil acidity correction as dolomite; has a greater capacity to supply Mg; and serves as a source of $\mathrm{Zn}$. However, the release of $\mathrm{Zn}$ contained in Zincal ${ }^{\text {ix }}$ is slower than that observed with the application of $\mathrm{Zn}$ sulfate.

Zincal $^{\mathrm{Tw}}$ and dolomite are equally efficient in decreasing the acidity of and $\mathrm{Al}^{3+}$ availability; and increasing base saturation and the $\mathrm{Ca}^{2+}$ and $\mathrm{Mg}^{2+}$ availability in two tropical soils, Red Latosol and Quartzarenic Neosol.

\section{AUTHORS' CONTRIBUTION}

Conceptualization: Cavalli E., Mellis E. V., Abreu, C.A.; Data Curation: Cavalli E., Mellis E., Abreu, C.A., Teixeira L. A. J., Cavalli C., Lange A.; Formal Analysis: Cavalli E., Mellis E. V., Abreu, C.A., Teixeira L. A. J., Cavalli C., Lange A.; Investigation: Cavalli E., Mellis E. V., Abreu, C.A., Cavalli C., Lange A.; Methodology: Cavalli E., Mellis E. V., Abreu, C.A.; Project Administration: Cavalli E., Mellis E. V., Abreu C.; Resources: Cavalli E., Mellis E. V., Abreu, C.A., Teixeira L. A. J.; Software: Cavalli E., Mellis E. V., Abreu, C.A., Teixeira L. A. J., Cavalli C., Lange A.; Validation: Cavalli E., Mellis E. V., Abreu, C.A., Teixeira L. A. J., Cavalli C., Lange A.; Visualization: Cavalli E., Mellis E. V., Abreu, C.A., Teixeira L. A. J., Cavalli C., Lange A.; Writing - Original Draft Preparation: Cavalli E., Mellis E. V., Abreu, C.A., Cavalli C., Lange A.; Writing - Review \& Editing: Cavalli E., Mellis E. V., Abreu, C.A., Teixeira L. A. J., Cavalli C., Lange A.; Supervision: Mellis E. V., Abreu, C.A.

\section{DATA AVAILABILITY STATEMENT}

The datasets generated and/or analyzed during the current study are available from the corresponding author on reasonable request.

\section{FUNDING}

Coordenação de Aperfeiçoamento de Pessoal de Nível Superior

[https://doi.org/10.13039/501100002322]

Fundação de Apoio à Pesquisa Agrícola

\section{ACKNOWLEDGMENTS}

We thank Coordenação de Aperfeiçoamento de Pessoal de Nível Superior (CAPES) for the scholarship of the first author, and Support Foundation for Agricultural Research (Fundag/Nexa/Víter Agro) for funding the research project.

\section{REFERENCES}

[Embrapa] Empresa Brasileira de Pesquisa Agropecuária. (2013). Sistema brasileiro de classificação de solos. 3rd ed. Brasília, DF: Embrapa Alloway, B. J. (2008). Zinc in soils and crop nutrition. 2nd ed. Brussels, Belgium and Paris, France: IZA and IFA. 
Barber, S. A. (1984). Liming materials and practices. In F. Adams. (Ed.), Soil acidity and liming. 2nd ed. (p. 171-209). Madison, WI: American Society of Agronomy. https://doi.org/10.2134/agronmonogr12.2ed.c4

[Brazil]. Ministério da Agricultura, Pecuária e Abastecimento. Secretaria de Defesa Agropecuária. Coordenação-geral de Apoio Laboratorial. (2014). Manual de métodos analíticos oficiais para fertilizantes minerais, orgânicos, organominerais e corretivos. Brasília, DF: MAPA/SDA/CGAL. 220 p.

[Brazil]. (2006). Instrução normativa SDA n. 27, de 5 de junho de 2006, alterada pela IN SDA n. 7, de 12 de abril de 2016, republicada em 02 de maio de 2016. [Access Mar. 5, 2019] .Available at: http://www.agricultura.gov.br/assuntos/insumos-agropecuarios/insumosagricolas/fertilizantes/legislacao/in-sda-27-de-05-06-2006-alterada-pela-in-sda-07-de-12-4-16-republicada-em-2-5-16.pdf.

Calonego, J. C., Mora, V. S., Santos, C. H. and Oliveira, L. (2012). Calagem e silicatagem em solo incubado com diferentes umidades. Colloquium Agrariae, 8, 46-56.

Camargo, O. A., Moniz, A. C., Jorge, J. A. and Valadares, J. M. A. S. (1986). Métodos de análise química, mineralógica e física de solos do Instituto Agronômico de Campinas. Boletim técnico 106. Campinas: Instituto Agronômico.

Chaves, L. H. G. and Farias, C. H. A. (2008). Escória de siderurgia e calcário na correção da acidez do solo e na disponibilidade de cálcio, magnésio e fósforo. Caatinga, 21, 75-82.

Ferreira, D. F. (2011). Sisvar: a computer statistical analysis system. Ciência e Agrotecnologia, 35, 1039-1042.

Gomes, M. A. F., Ribeiro, A. C., Costa, L. M. and Moura Filho, W. (1996). Influência de ferro e alumínio amorfos do solo na reatividade de quatro corretivos de acidez. Revista Ceres, 43, 444-453.

Haby V. A., Russell M. P. and Skogley E. O. (1993). Testing soils for potassium, calcium and magnesium. Soil Science Society of America, 3, 181-227.

Islabão, G. O., Vahl, L. C., Timm, L. C., Paul, D. L. and Kath, A. H. (2014). Rice husk ash as corrective of soil acidity. Revista Brasileira de Ciência do Solo, 38, 934-941. https://doi.org/10.1590/S0100-06832014000300025

Lasso, P. R. O., Vaz, C. M. P., Bernardi, A. C. C., Oliveira, C. R. and Bacchi, O. O. S. (2013). Avaliação do uso de resíduos de construção e demolição reciclados como corretivo da acidez do solo. Revista Brasileira de Ciência do Solo, 37, 1659-1668.

Lo Monaco, P. A. V., Matos, A. T., Eustáquio Júnior, V., Ribeiro, I. C. A. and Teixeira, D. L. (2012). Utilização do farelo de conchas de vôngole na adsorção de fósforo e como corretivo da acidez do solo. Engenharia Agrícola, 32, 866-874.

Martins, V., Silva, D. R. G., Marchi, G., Leite, M. C. A., Martins, E. S., Gonçalves, A. S. F. and Guilherme, L. R. G. (2015). Effect of alternative multinutrient sources on soil chemical properties. Revista Brasileira de Ciência do Solo, 39, 194-204.

McLean, E. O. and Brown, J. R. (1984). Crop response to lime in the Midwest United States. In F. Adams (Ed.). Soil and liming. 2nd ed. Madison, WI: American Society of Agronomy.

Mellis, E. V., Quaggio, J. A., Cantarella, H., Teixeira, L. A. J. and Cavalli, E. (2018). Nutrição e adubação da cultura da cana-de-açúcar: Micronutriente. In R. M. Prado and C. N. S. Campo (Eds.), Nutrição e adubação de grandes culturas. (p. 301-326). Jaboticabal: FCAV.

Mello, J. C. A., Villas Bôas, R. L., Lima, E. V., Crusciol, C. A. C. and Büll, L. T. (2003). Alterações nos atributos químicos de um Latossolo distroférrico decorrentes da granulometria e doses de calcário em sistemas plantio direto e convencional. Revista Brasileira de Ciência do Solo, 27, 553-561. https://doi.org/10.1590/S0100-06832003000300017

Morelli, J. L., Dalben, A. E., Almeida, J. O. C. and Dematte, J. L. I. (1992). Calcário e gesso na produtividade da cana-de-açúcar e nas características químicas de um Latossolo de textura média álico. Brasileira de Ciência do Solo, 16, 187-194.

Moser, F. (1933). The calcium-magnesium ratio in soils and its relationship to crop growth. American Journal of Agronomy, $25,365-377$. 
Pegoraro, R. F., Silva, I. R., Novais, F. R., Mendonça, E., Gebrim, F. O. and Moreira, F. F. (2006). Fluxo difusivo e biodisponibilidade de zinco, cobre, ferro e manganês no solo: influência da calagem, textura do solo e resíduos vegetais. Revista Brasileira de Ciência do Solo, 30, 859-868. https://doi.org/10.1590/S0100-06832006000500012

Quaggio, J. A. (2000) Acidez e calagem em solos tropicais. Campinas: Instituto Agronômico.

Quaggio, J. A., Gallo, P. B. and Mascarenhas, H. A. A. (1995). Agronomic efficiency of limestones with different acid-neutralizing capacity, under field condition. In: R. A. Date, N. J. Grundon, G. E. Rayment and M. E. Probert (Eds.). Plant-soil interactions at low pH: principles and management. Developments in plant and soil sciences (p. 491-496). Dordrecht: Springer. https://doi.org/10.1007/978-94-011-0221-6_75

Raij, B., Andrade, J. C., Cantarella, H. and Quaggio, J. A. (2001). Análise química para a avaliação da fertilidade de solos tropicais. Campinas: Instituto Agronômico.

Raij, B., Cantarella, H., Camargo, A. P. and Soares, E. (1982). Perdas de cálcio e magnésio durante cinco anos em ensaio de calagem. Revista Brasileira de Ciência do Solo, 6, 33-37.

Raij, B., Cantarella, H., Quaggio, J. A. and Furlani, A. M. C. (1997). Recomendação de adubação e calagem para o Estado de São Paulo.

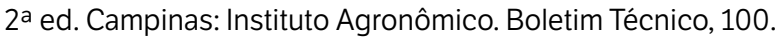

Raymundo, V., Neves, M. A., Cardoso, M. S. N., Bregonci, I. S., Lima, J. S. S. and Fonseca, A. B. (2013). Resíduos de serragem de mármores como corretivos da acidez do solo. Revista Brasileira de Engenharia Agrícola e Ambiental, 17, 47-53.

Rossetto, R., Dias, F. L. F., Vitti, A. C. and Cantarella, H. (2014). Fertility maintenance and soil recovery in sugarcane crops. In L. A. B. Cortez (Coord.). Sugarcane bioethanol — R\&D for Productivity and Sustainability. (p. 381-404). São Paulo: Editora Edgard Blücher,

Rossetto, R., Spironello, A., Cantarella, H. and Quaggio, J. A. (2004). Calagem para a cana-de-açúcar e sua interação com a adubação potássica. Bragantia, 63, 105-119.

Shuman, L. M. and Duncan, R. R. (1990). Soil exchangeable cations and aluminum measured by ammonium chloride, potassium chloride, and ammonium acetate. Communications in Soil Science and Plant Analysis, 21, 1217-1228.

Simon, C. R., Cory R. B. and Sumner M. E. (1979). Effect of varying Ca:Mg ration on yield and composition of corn and alfalfa. Communications in Soil Science and Plant Analysis. 10, 153-162.

Srivastava, A. K. and Rai, M. K. (2012). Sugarcane production: impact of climate change and its mitigation. Biodiversitas, $13,214-227$. https://doi.org/ 10.13057/biodiv/d130408 